\title{
Agronomical performance of soybean genotypes infected by Cowpea Mild Mottle Virus in various level of nitrogen
}

\author{
ENDRIK NURROHMAN ${ }^{1}$, SITI ZUBAIDAH ${ }^{1, \vartheta}$, HERU KUSWANTORO ${ }^{2, v v}$ \\ ${ }^{1}$ Department of Biology, Faculty of Mathematics and Natural Sciences. Universitas Negeri Malang. J1. Semarang No. 5, Malang 65145, East Java, \\ Indonesia. Tel./fax.: +62-341-551312, `email: siti.zubaidah.fmipa@um.ac.id \\ ${ }^{2}$ Indonesian Legume and Tuber Crops Research Institute, Indonesian Agency for Agricultural Research and Development. Jl. Raya Kendalpayak Km. 8, \\ Kendalpayak, Pakisaji, Malang 65101, East Java, Indonesia. Tel./fax.: +62-341-801496, vemail: herukusw@gmail.com
}

Manuscript received: 11 December 2018. Revision accepted: 19 April 2019.

\begin{abstract}
Nurrohman E, Zubaidah S, Kuswantoro H. 2019. Agronomical performance of soybean genotypes infected by Cowpea Mild Mottle Virus in various level of nitrogen. Biodiversitas 20: 1255-1263. Nitrogen is one of the essential nutrients during the process of vegetative and generative growth of soybean. Nitrogen deficiency during the growth can adverse to agronomical plant traits. This study was aimed to discover the influence of nitrogen on the agronomical traits of the soybean lines and varieties infected by cowpea mild mottle virus (CpMMV). The trial was arranged in factorial randomized complete block design with three replications. The first factor was the nitrogen dose consisting of four nitrogen doses while the soybean genotypes as the second factor consisted of seven genotypes. The results showed that nitrogen did not influence the plant resistance to CpMMV. The plant resistance was more affected by the genotype. The soybean genotypes were significant differences in the pod length, the pod width, and the flowering date. The interaction between genotype and nitrogen was found in the number of filled pods, the number of unfilled pods plant ${ }^{-1}$, the number of reproductive nodes plant ${ }^{-1}$, the number of total pods and the seed weight plant ${ }^{-1}$. The relationship in agronomic traits showed that significant positive correlations were found between number of filled pods with number of total pods, seed length with seed width and seed thickness, while the significant negative correlations were found between pod thickness with number of unfilled pods and maturity date with weight of 50 seeds.
\end{abstract}

Keywords: Agronomical traits, Cowpea Mild Mottle Virus, nitrogen, soybean

\section{INTRODUCTION}

The decrease in soybean production caused by natural condition, such as pests attack, diseases (Sutrisno and Kuswantoro 2016), infertile soil (Jumrawati 2008) and other biotic and abiotic stresses. Many organisms can attack soybean and cause the disease. Cowpea mild mottle virus (CpMMV) is a virus that causes the primary leaf disease of soybean (Zubaidah and Kuswantoro 2016). This disease has infected soybean in many countries including Indonesia (Brown 2014). The infected soybean yield decreases up to $90 \%$ (Sinclair 1993).

CpMMV infection in the soybean cause leaf damage in the leaf and systemic symptom as a mosaic or yellow spot so that the vegetative and generative growth is interrupted. The symptom of CpMMV disease in the infected soybean in which the leaf is pale green, the leaf surface wrinkled, and the leaf is yellowish mosaic and irregular (Wartono et al. 2011). CpMMV can distract the vegetative growth of the plant (Brown 2014; Ebony et al. 2010), and reduce soybean productivity (Laguna et al. 2006). The infected leaf of soybean is damaged and easy to fall (Suryadi et al. 2012; Andayani 2010), the leaves become chlorosis and necrosis, and all parts of the plant are shrunk (Brown 2014). Therefore, the pods cannot be formed perfectly and the seed yield was reduced (Suryadi et al. 2012).

The effort of soybean breeding for virus resistance is needed to maintain and increase the domestic production of soybean. Nowadays, there are several resistant lines that are resistant to Cowpea Mild Mottle Virus (CpMMV) with special traits, but the pods were small in size, so it is not preferred by the farmers. Many ways to increase the soybean yield and disease resistance are by increasing the potential of plant production, maintaining the soil water, and fertilizing the plant (Ahsan et al. 2012).

The nutrient can raise the growth and productivity of soybean, one of which is nitrogen. Nitrogen has a significant role in plant growth (Mehmet 2008; Yagoub et al. 2012) and affects to increase the soybean yield (Chafi et al. 2012). Nitrogen application to the soil can accelerate the soybean growth (Ahsan 2012), increase the soybean yield (Seghatoleslami et al. 2012; Wood et al. 1993), and enhance the soybean production by increasing the number and weight of pods (Chafi et al. 2012). The plant uses nitrogen to form morphology from the vegetative organ of the plant and generative organs such as flower and pod. When the flowering process stops, the pod forming and seed growth are getting fast, the shape and the size of the pod will be maximum during the first period of seed maturity followed by the pod color change meaning that the pod is mature. Nitrogen can increase the soybean plant crop by increasing the number of pods (Seghatoleslami et al. 2009), and the pod weight of soybean plant (Chafi et al. 2012). This study was aimed to discover the influence of nitrogen on the agronomical traits of the soybean lines and varieties infected by cowpea mild mottle virus (CpMMV). 


\section{MATERIALS AND METHODS}

\section{Site and design}

The study was carried out at Indonesian Legume and Tuber Crops Research Institute, Malang. The trial was arranged in factorial randomized complete block design with three replications. The first factor was nitrogen consist of four levels of dose, included N1 $\left(0 \mathrm{~g} \mathrm{polybag}^{-1} \mathrm{~N} 2\right.$ $\left(0.180 \mathrm{~g} \mathrm{polybag}^{-1}\right), \mathrm{N} 3\left(0.363 \mathrm{~g}^{-1}\right.$ polybag $^{-1} \mathrm{~N} 4(0.593 \mathrm{~g}$ polybag $\left.^{-1}\right)$, and the second one was soybean resistant genotypes consist of five lines (UM 4-1, UM 7-2, UM 2-4, UM 7-6, UM 6-2), and two checks varieties (Wilis and Gumitir). The lines derived from Gumitir $\times$ MLGG 0021 crossing. Wilis and Gumitir were chosen as the check varieties because they were resistant and susceptible to CpMMV respectively. There were four plants for each treatment unit per replication. To maintain the normal growth, the plants were fertilized using $0.55 \mathrm{~g} \mathrm{polybag}^{-1}$ of phosphate fertilizer and $0.917 \mathrm{~g} \mathrm{polybag}^{-1}$ of potassium.

\section{Soil preparation and fertilizers applications}

The soil planting media was prepared one week before planting. After that, the soil was dried in the sun to reduce the soil water content, so it did not agglomerate easily in the soil sieving and filtering process. Two seeds were planted into planting hole, which two holes in every polybag. The fertilizers were sowed into the hole which were made between the planting hole. The nitrogen $(\mathrm{N})$, phosphate $(\mathrm{P})$ and potassium $(\mathrm{K})$ fertilizers were applied based on the doses determined in the treatments. The plants were maintained by watering twice a week and weeding once a week.

\section{CpMMV transmission}

Thirty days before CpMMV transmission was carried out, Bemisia tabaci population as vector of CpMMV was prepared for transmission. Bemisia tabaci came from other hosts in the experimental field. The presence of this insect is very common in Iletri's experimental field. As Bemisia tabaci population was ready, at least 100 insects per plant, the main experiment was done by placing the polybags in the middle of the experimental field with abundant of Bemisia tabaci. The Bemisia tabaci population is presented in Fig. 1. The CpMMV was transmitted from the infected plants to the experimental plants by the Bemisia tabaci. This technique allowed a natural transmission of CpMMV. The infection was verified based on the CpMMV symptoms. The disease severity was calculated according to Zubaidah and Kuswantoro (2016).

\section{Observation and data analysis}

The observation was done to all plants. The observation was carried out to the Bemisia tabaci population, beside the agronomical traits. The agronomical traits observed were maturity date, the plant height, the number of branches of plant $^{-1}$, the number of reproductive nodes plant ${ }^{-1}$, the number of filled pods plant ${ }^{-1}$, the number of unfilled pods plant $^{-1}$, the number of seeds plant ${ }^{-1}$, the seed weight plant ${ }^{-1}$, and the weight of 100 seeds. When the leaves turned yellow and fall and the pods were brown, the harvest was done. Analysis of variance was computed by using the Statistical Program for Social Science (SPSS) 2.1. The following up test was done by using LSD $5 \%$ of significantly different variables.

\section{RESULTS AND DISCUSSION}

The population of Bemisia tabaci was more than required (Fig. 1). Wartono et al. (2011) reported that 39 insects per 10 plants lead to disease incidence of $97 \%$. The average of the population was about 30 insects per trifoliate leaf (Fig. 1). It means that on one plant, there were more than 150 insects depend on the age of the plant. Bemisia tabaci preferred young leaf than older leaf. The highest number of Bemisia tabaci per trifoliate leaf was achieved on 21 DAP (V3), and continued decrease on 28 (V4), 35 (R1), and 42 DAP (R2) (Fig. 1). The soybean growth stage in Indonesia is different from the other countries, because Indonesia's climate is tropic. In tropical climate, the soybean age is shorter than in subtropical climate (Kuswantoro et al. 2017b). The highest attack of insect is at $\mathrm{V} 2$, because the leaf in this growth stage is softer than other growth stages. The older plant organ, the harder plant tissue. Besides, the young leaf also has very short trichome where the insect's stylet can reach the leaf surface easily. The density and the angle of trichome have negative correlation with the population of Bemisia tabaci's eggs (Taggar and Gill 2012).

The results showed that nitrogen treatment did not affect the disease severity but the genotype did. The similar effects of nitrogen treatment may be due to the variability of virus strain and environmental condition (Sinclair 1993). Disease severity of the genotypes at 21 and 35 DAP was significantly different, but not at 28 and 42 DAP (Fig. 2). UM 7-6 showed the highest disease severity at 21 DAP, while the lowest was achieved by UM 6-2. At 28 DAP the ranks of the genotypes were changed, where the highest disease severity was achieved by UM 2-4 and the lowest was achieved by UM 4-1 and UM 7-6. The disease severity increased according to the age, where the highest disease severity was achieved at 42 DAP. This phenomenon is different against the previous study reported by Zubaidah and Kuswantoro (2016) where the disease severity decreases after 35 DAP (R1). It may be due to the high population of Bemisia tabaci in the experiment (Fig. 1). Jiu et al. (2007) also reported the higher population on virusinfected plant than the healthy plant.

The results showed that the soybean genotype gave various responses due to the genotype, nitrogen, and interaction between infected genotype $\times$ nitrogen. The infected genotype $\times$ nitrogen interaction significantly influenced the agronomical traits of soybean in the number of filled pods plant ${ }^{-1}$, the number of unfilled pods plant ${ }^{-1}$, the number of reproductive nodes plant ${ }^{-1}$, the number of total pods plant ${ }^{-1}$, and the seed weight plant ${ }^{-1}$.

The longest pod was found at Gumitir, but it was not significantly different with Wilis, UM 6-2 and UM 2-4 (Fig. 3). The pod size and the ability to absorb the nutrient, including nitrogen was genetically influenced. Nitrogen is 
an important nutrient for plant growth (Mehmet 2008). The nitrogen needed by the plant to develop organs from vegetative to generative such as flower and pod. $\mathrm{N}$ contents in leaves and stems in the V5 stage increase with the application of $\mathrm{N}$, where leaf, stem total shoot dry matters increase in V5 (Werner et al. 2016). When the flowering process stops, the pod was formed and seed growth faster. The shape and the size of the pod is maximum during the first period of seed maturity followed by the changing of pod color, it means that the pod is mature. Nitrogen can increase the soybean yield by increasing the number of pods (Seghatoleslami et al. 2012), and the pod weight (Chafi et al. 2012). Stem and total shoot dry matters in R5 increase with $\mathrm{N}$ application (Werner et al. 2016). The $\mathrm{N}$ uptake in physiological maturity stage is higher than in flowering stage (Mahesh et al. 2017).

The Gumitir variety showed the widest pod, but it was not significantly different with Wilis, UM 4-1, and UM 7-2 (Fig. 4). The plant pod width included the different size of pods. The different size of pod and seed of the genotypes was caused by many factors such as genetical and environmental condition. The environmental condition that influences the pod size is nutrient availability. There are many essential nutrients needed by the plant; one of them is nitrogen. Nitrogen is required in soybean growth and organ development including the pod size. Nitrogen is also important in forming protein, enzyme, nucleotide, and compound like lignin which is useful for the vegetative and generative growth, including pod size (Meliala 2009). Nitrogen can increase the number and weight of pods, and thus it can increase the production (Chafi et al. 2012).

The Wilis variety showed the highest number of filled pods in $\mathrm{N} 1$, and the number of filled pods in the other $\mathrm{N}$ doses was lower. There was no genotype similar to Wilis variety where the $\mathrm{N} 1$ showed the highest number of filled pods, except UM2-4 which was relatively similar to Wilis variety. All other genotypes had equal or higher number of filled pods (Fig. 5). The availability of nutrition is one of the key factors in the process of soybean pod and seed formation. Nitrogen is an essential element in the process of seed formation (Ohyama et al. 2017). Nitrogen deficiency during seed filling stage cause a failure in the process of seed formation. The number of pods is also influenced by fertilizer as environmental factor. The fertilizer ameliorated the physical, chemical, and biological soil characteristic. Nitrogen can accelerate the photosynthesis process, so that the vegetative growth stimulated. The availability of nitrogen within the soil produces result in much protein of the plant so that it increases the number of pods of the plant. However, Wilis showed the highest number of filled pods with the lowest $\mathrm{N}$ doses. It may be due to the response of Wilis was different than other genotypes, where the lowest $\mathrm{N}$ doses in this experiment were the optimum dose for Wilis.

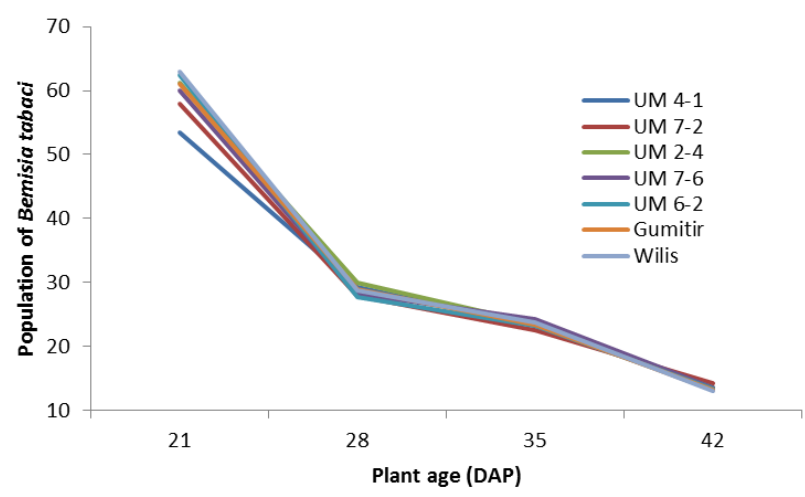

Figure 1. Population of Bemisia tabaci on a leaf of soybean genotypes

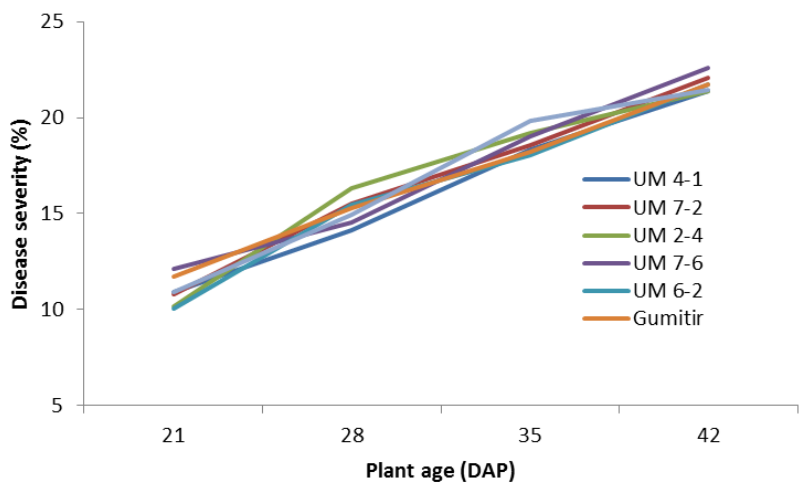

Figure 2. Disease severity of soybean genotypes

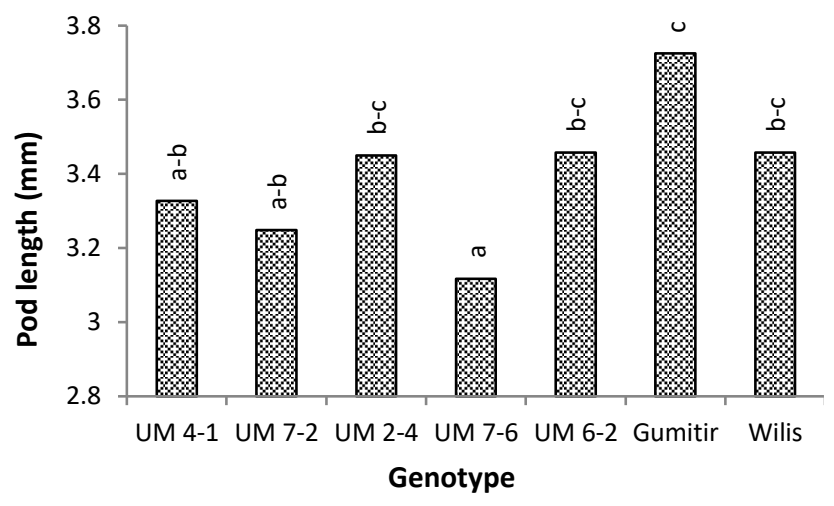

Figure 3. Pod length of some soybean genotypes

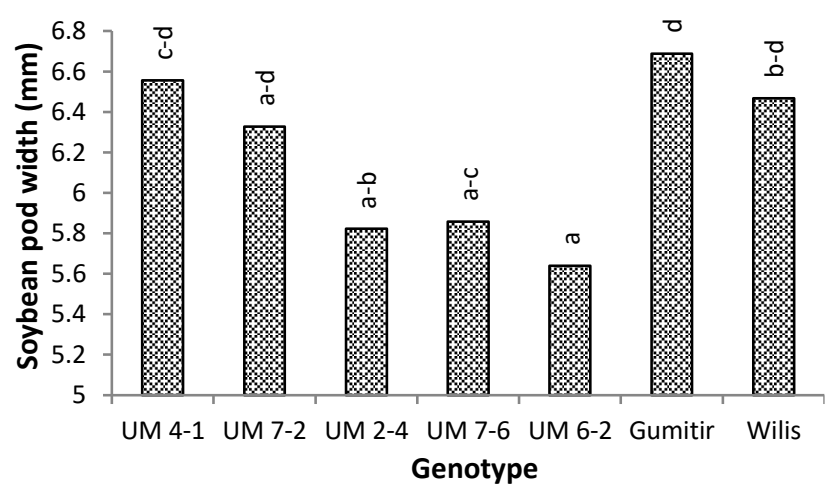

Figure 4. Pod width of some soybean genotypes 
UM 6-2 in N1 had the highest number of unfilled pods plant $^{-1}$. This treatment combination (UM 6-2 in N1) also showed the highest number of unfilled pods than other treatment combinations. Unlike the number of filled pods, UM 2-4 showed insignificant difference in the four $\mathrm{N}$ doses. Gumitir variety showed similar pattern with UM 24 , where the $\mathrm{N}$ doses were not significantly different (Figure 6). The less nitrogen was given, the number of unfilled pods plant ${ }^{-1}$ was getting higher. It means that the availability of nitrogen influences the pod formation of the plant. Unfilled pods plant ${ }^{-1}$ is a condition in which the seed cannot be formed within the pod. The unfilled pods plant ${ }^{-1}$ can be due to many factors and one of which is the adequacy of nutrients during the process of seed formation and ripening within the pod. One of the nutrients needed in the process of seed and pod formation of soybean is nitrogen. Mehmet (2008) reported that nitrogen is an essential nutrient for plant and it greatly influences the plant growth. Nitrogen application in the soil can increase the production of soybean by increasing the number and weight of pod (Chafi et al. 2012; Asanuma et al. 1992). A genotype has different responses to different environmental conditions, including its response in nodulation. In salinity, the salinity tolerant genotypes exhibit greater nodulation (Song et al. 2017). This different response is due to the different genes exist in a genotype. Some genes controlling soybean nodulation have been discovered, involving genes in soybean and rhizobia (Liu et al. 2017; Tang et al. 2016; Yan et al. 2015). The inoculated plants produce higher nodule numbers, nodule weight, shoot and root biomass, eventually producing higher pod, stover, and seed yield (Alam et al. 2015). However, on nitrate intolerant soybean, nitrogen additions decrease soybean nodulation (McCoy et al. 2018).

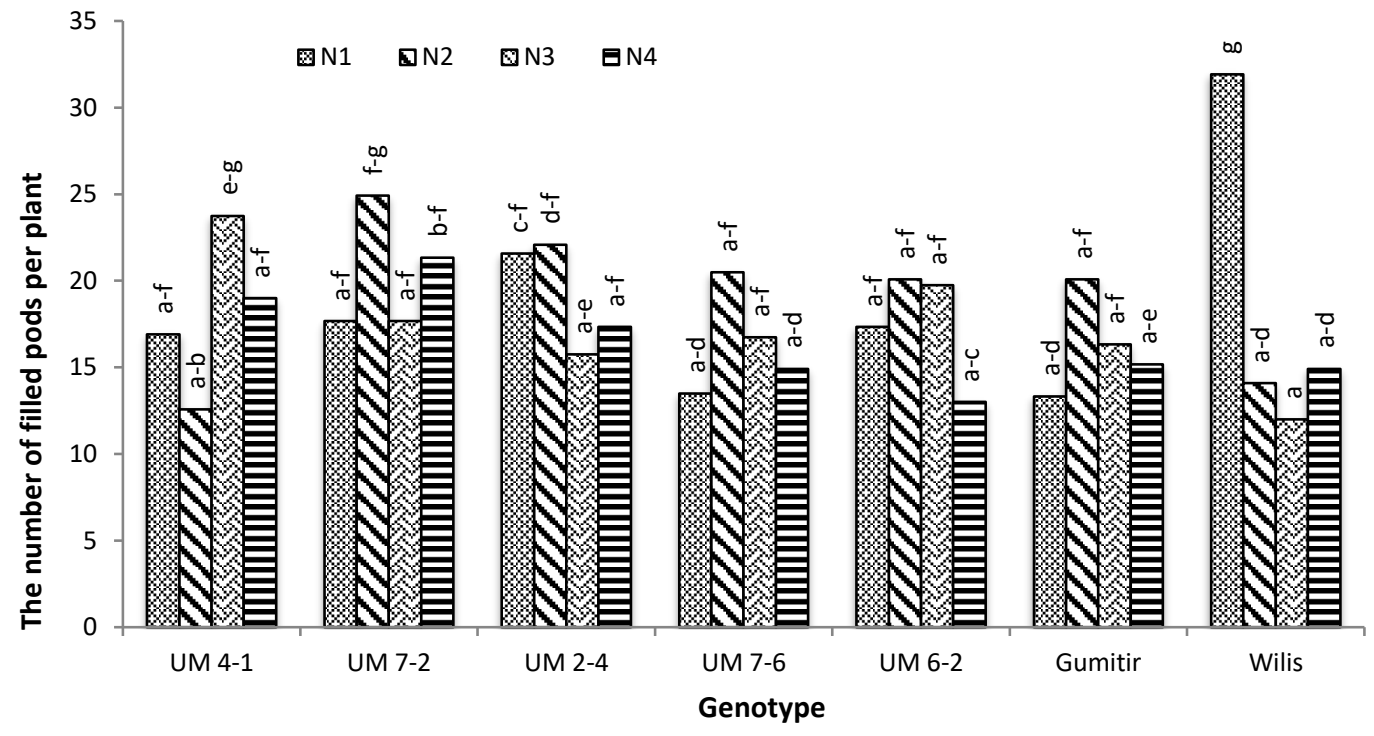

Figure 5. Interaction of genotype and nitrogen dose in the number of filled pods plant ${ }^{-1}$ of soybean

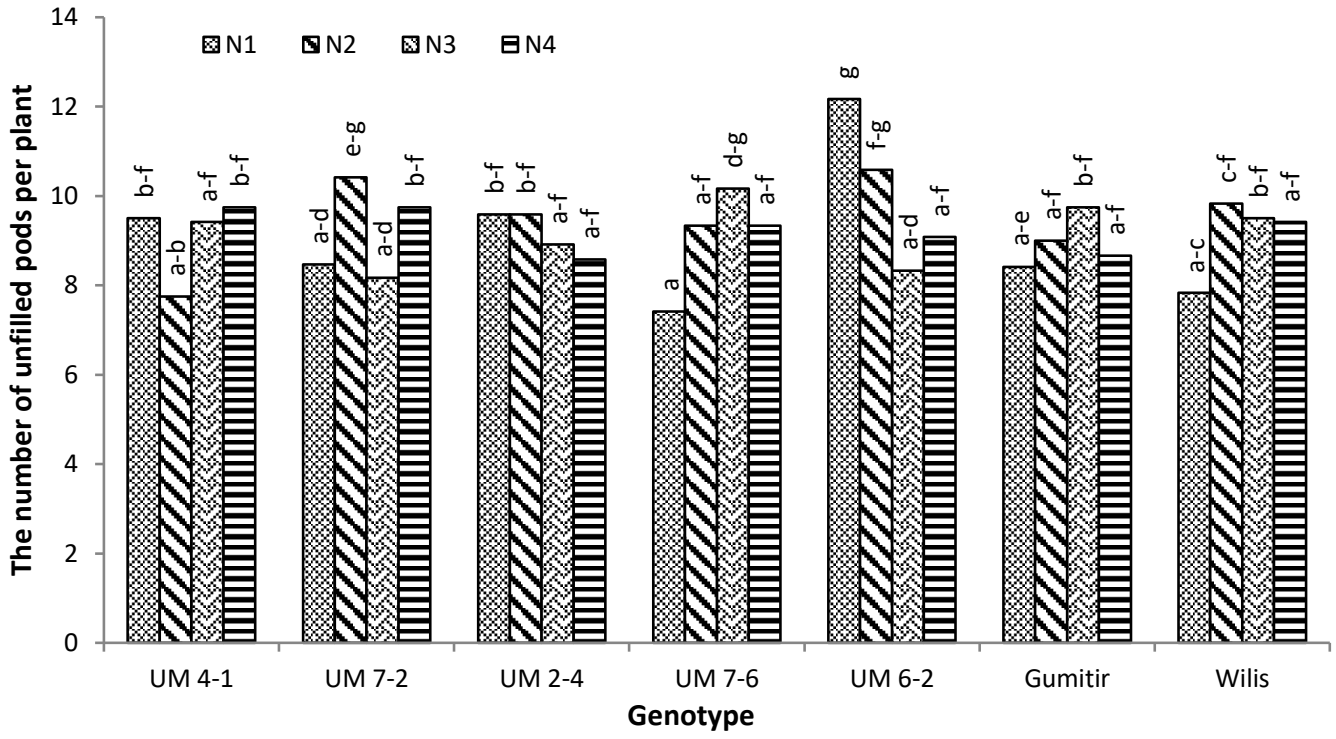

Figure 6. Interaction of genotype and nitrogen dose in the number of unfilled pods plant ${ }^{-1}$ of soybean 


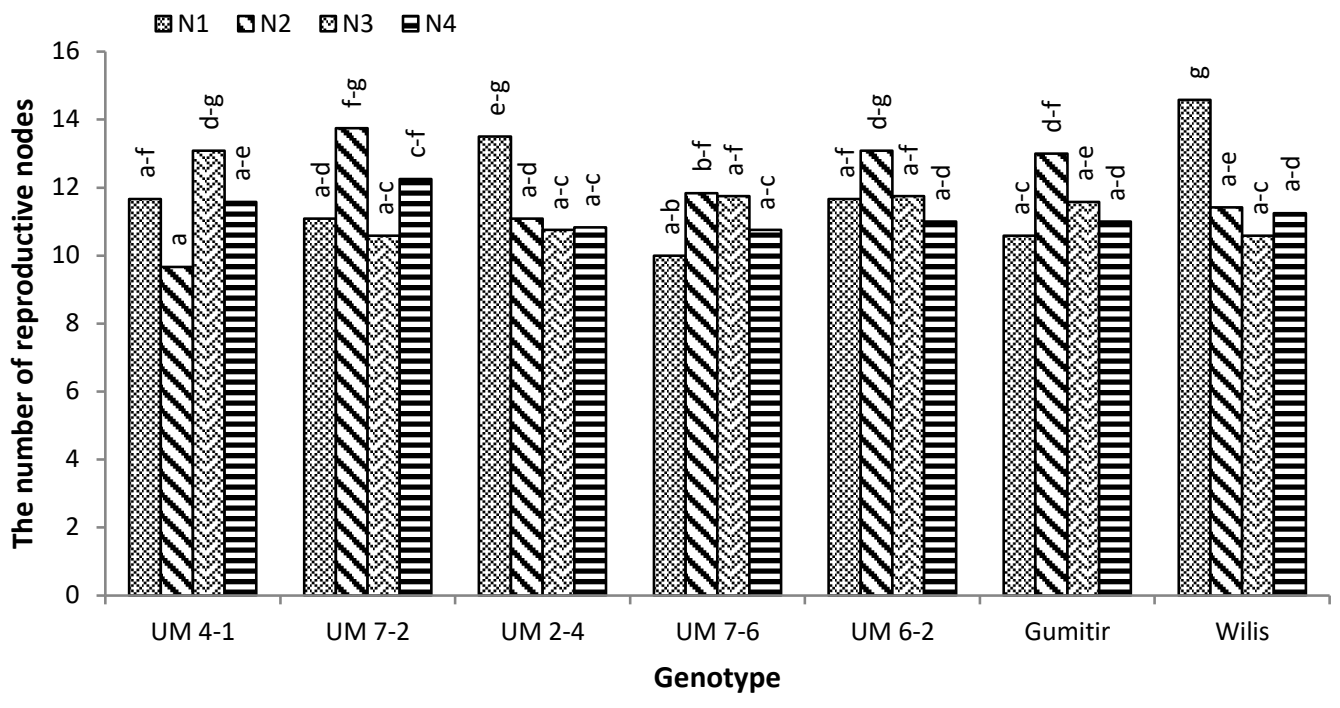

Figure 8. Interaction of genotype and nitrogen dose to the reproductive nodes of soybean

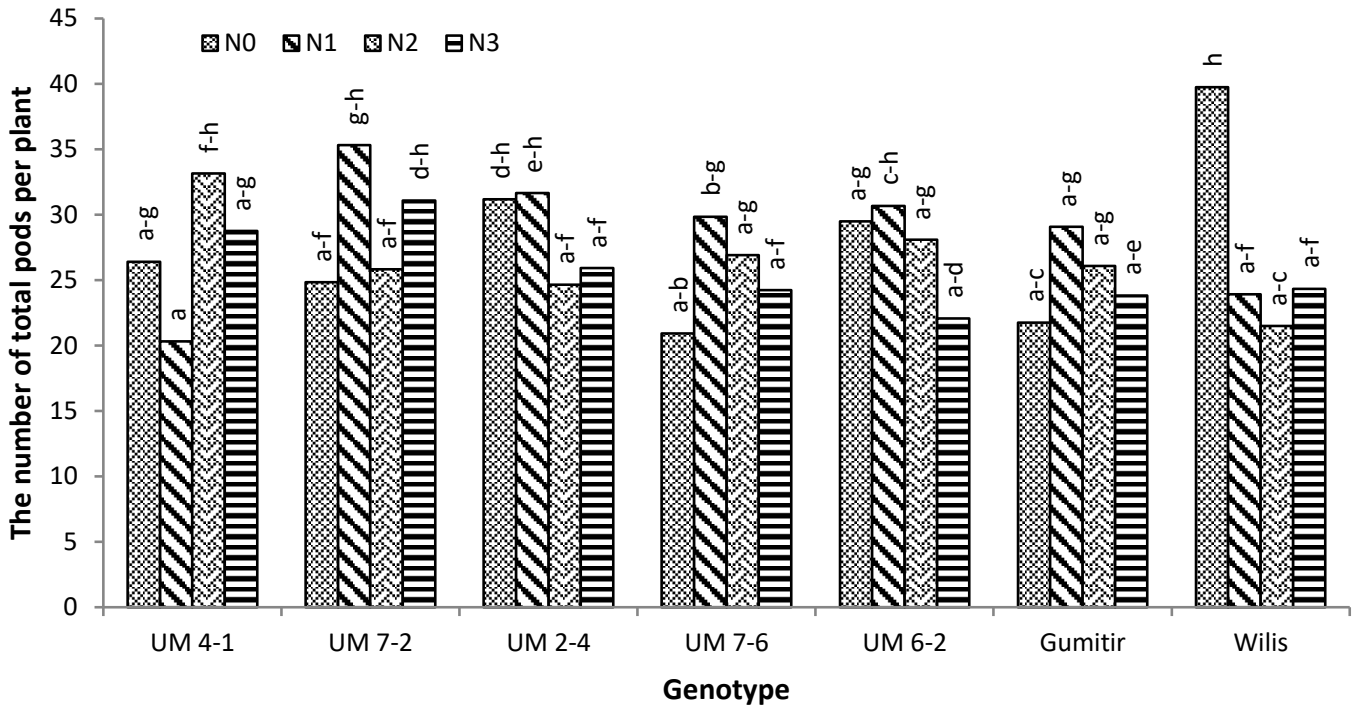

Figure 9. Interaction of genotype and nitrogen dose to the number of total pods plant ${ }^{-1}$ of soybean

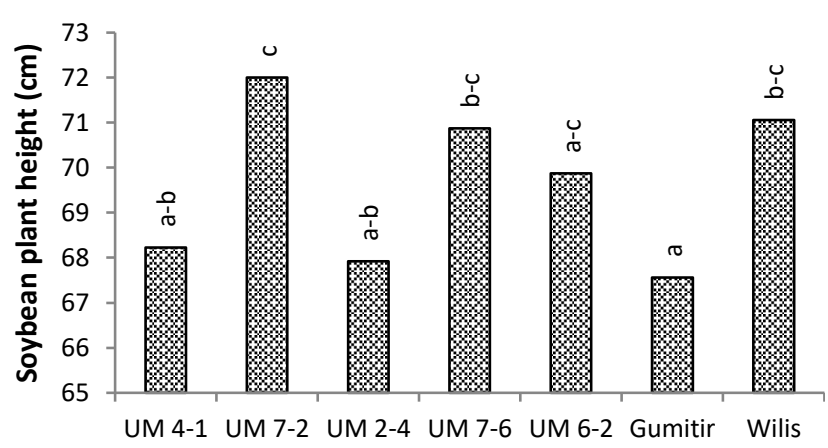

Genotype

Figure 7. Performance of plant height of some soybean genotypes
UM 7-2 line is the highest plant, but it was not significantly different with Wilis, UM 7-6 and UM 6-2 (Fig. 7). The plant height, like the other agronomical traits influenced by the genetical and environmental factors Nitrogen as one of the environmental factors is needed in metabolism and biochemistry processes of the plant during the growth. Insufficient nitrogen caused the obstacles in plant growth and development. (Mehmet 2008). Nitrogen deficient caused slow growth, as a result, the plant is thin, dwarf and has brown color (Meliala 2009). Mehmet (2008) showed that nitrogen was related to the increase of plant height and it has a positive effect to produce branches; the higher nitrogen fertilizer, the higher growth of the plant height and the number of the branches. 
Wilis variety in N1 showed the highest number of reproductive nodes. However, the reproductive nodes were not significantly different from UM 6-2 and UM 7-2 lines with an N3 dose, from UM 4-1 with an N4 dose, from UM 2-4 with an N1 dose (Fig. 8). Reproductive node is one of the stages in soybean growth. During the growth, the soybean plant needs the nutrient including nitrogen. Nitrogen is useful in forming protein, enzyme, nucleotide, and the compound like lignin which is important for the growth (Meliala 2009), and the development of soybean plant (Yagoub et al. 2012). Therefore, nitrogen is needed for the soybean plant growth and forming the parts of the plant including the reproductive nodes. Application of nitrogen to the soybean plant can increase the growth speed of the plant (Ahsan 2012). Golparvar et al. (2012) reported that by adding nitrogen fertilizer to the soil could increase the soybean growth and development.

Wilis variety in N1 showed the highest seed weight plant $^{-1}$, but it was not significantly different with UM 6-2, UM 2-4, and UM 7-2 lines with an N3 dose (Fig. 9). The Wilis variety had the highest number of total pods plant ${ }^{-1}$ compared to the other genotypes. The number of total pods plant $^{-1}$ is closely related to the number of the flower and the productive flower. The Wilis variety and UM 2-4 line were earlier in flowering compared to the other lines so it was potentially thought could produce more pods. Hasnah (2003) stated that the earlier of the flowering, the more pods were formed. Nitrogen was needed in pods formation (Wood et al. 1993). Each genotype has a specific dose of nitrogen to produce pods. Nitrogen showed a positive effect in increasing soybean yield by the increasing number of pods. (Seghatoleslami et al. 2012).

The Wilis variety in $\mathrm{N} 1$ had significantly higher seed weight compared to the other interactions. Wilis variety was a high yielding check variety in this study. The lines that had the seed weight plant $^{-1}$ next to Wilis were UM 4-1 and UM 7-2 (Fig. 10). The seed filling begins at R5. Islam et al. (2016) found that the nitrogen in vegetative organs begin to decrease at R6 as the consequence of nitrogen redistribution to the seeds. However, the elements translocation have begun from R1 to R7, where the levels of essential elements in nodules decrease and nonessential elements increase in $\mathrm{N}$ treatments (Chu at al. 2016). Nitrogen also can enhance soybean seed weight. Marlina et al. (2015) reported that nitrogen fertilizer provides significant influence to the plant dry weight, the plant height, the days to flowering, the harvest date, the number of pods, the number of filled pods plant ${ }^{-1}$, and the dry seed production. Efendi (2010) showed that nutrient application in the form of fertilizer could increase soybean productivity.

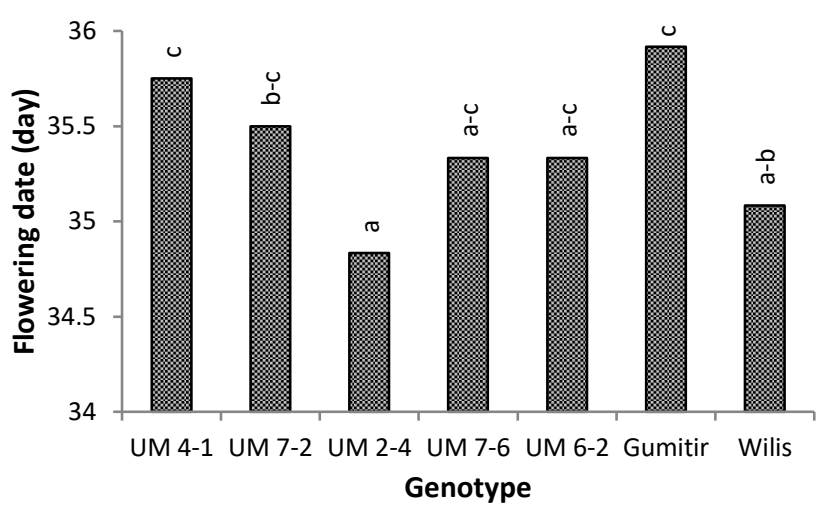

Figure 11. Days to flowering of some soybean genotypes

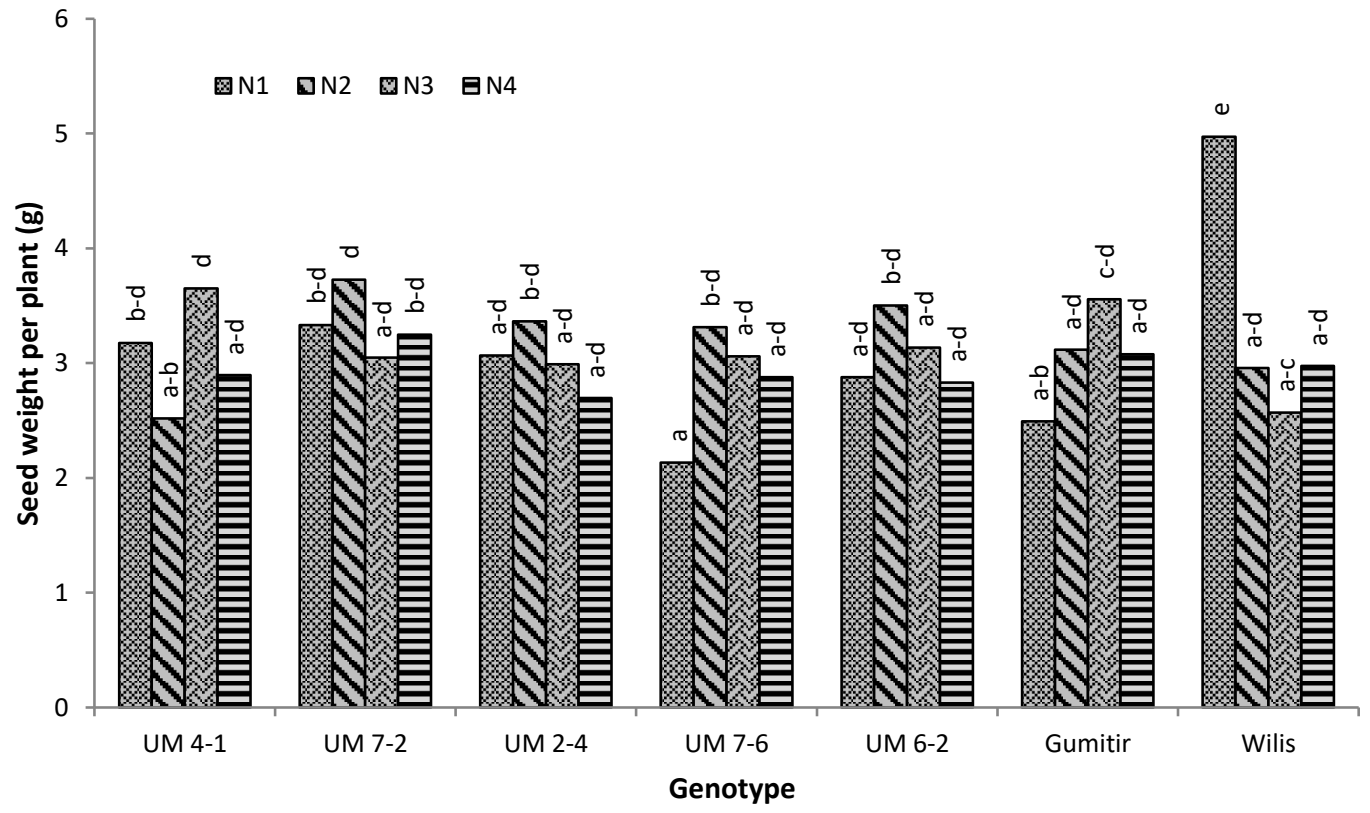

Figure 10. Interaction of genotype and nitrogen dose in the seed weight plant $^{-1}$ of soybean 
Nitrogen is useful in all soybean growth stages. Nitrogen as starter fertilizer increase plant biomass in V3V4 and R1 and grain yield (Osborne and Riedell 2006). The highest nitrogen use is found in R3 stage and decline during R5-R7 stage (Tewari et al. 2007). R3 is the beginning pod formation, where pod enlargement needs many nutrients, especially nitrogen. Zhao et al. (2014) reported that the application of 400 and 800 ppm nitrogen in R1-R5 showed the highest total pod number. On other studies, Schiltz et al. (2005) reported that vegetative organs are the main place to accumulate exogenous $\mathrm{N}(86 \%)$ before seed filling initiation, while at the onset of seed filling exogenous $\mathrm{N}$ are distributed to the vegetative organs $(45 \%)$ and the seeds (the rest). Further, at seed filling stage, the $\mathrm{N}$ in seeds is redistributed from leaves $(30 \%)$, pod walls $(20 \%)$, roots (11\%), and stems (10\%) (Schiltz et al. 2005).

Based on the flowering date, Gumitir variety and UM 41, UM 7-2, UM 6-2, and UM 7-6 lines showed as a late flowering plant (Fig. 11). Flowering date is related to the growth of the plant. A plant grows up maximally as the organs formed, including the flowers and pods. Gumitir variety had the earliest flowering date due to the genetical and environmental factors, such as nitrogen. $\mathrm{N}$ treatment did not affect the flowering date. The genotype only influenced the flowering date. Therefore, the effect of the genotypes was higher than the nitrogen treatments. Besides the genetic factor, the other factors are the environment, the availability of nutrition and mineral like nitrogen influencing the growth regulation. The role of nitrogen is accelerating the growth process of plant entirely including stem and leaf. Nitrogen is the chlorophyll former so that if the chlorophyll increases, the photosynthesis increases as well. The availability of nitrogen increases the photosynthesis result and flowering process (Soverda and Hermawati 2009).

Based on the correlation analysis, the significant positive correlations were found on number of filled pods vs number of total pods, seed length vs seed width and seed thickness, while the significant negative correlations were found on pod thickness vs number of unfilled pods, and maturity date vs weight of 50 seeds (Table 1). Kuswantoro et al. (2017a) also reported a significant negative correlation between days to maturity and seed size. Seed size is an important trait because it can affect the soybean yield (Kuswantoro 2015; Kuswantoro et al. 2014).

The number of filled pods plant ${ }^{-1}$ with the number of total pods plant ${ }^{-1}$ had a correlation value of 0.972 . It means that both of them had a significant correlation. The difference between the number of total pods plant ${ }^{-1}$ was the result of a various number of flowers during the first period of forming and the level of falling off the reproduction organ so that the crop is dominantly influenced by the number of pods that could be formed maximally by the plant. The different variety of plants showed different growth and product although they were planted in the same environmental condition. The number of filled pods plant ${ }^{-1}$ is closely related to the number of pods produced by the plant (Chafi et al. 2012). The number of filled pods plant ${ }^{-1}$ produced by each plant influences the number of filled pods plant ${ }^{-1}$ (Mehmet 2008). Hakim (2012) reported that the increase in the number of total pods plant ${ }^{-1}$ is positively correlated with the increase in the number of filled pods plant $^{-1}$. A number of unfilled pods negative correlated to pod thickness. It may be the thickness pod affects the strength of pod, therefore, the pods fasten strongly at the node.

Table 1. Correlation analysis of each agronomical trait of soybean and disease severity

\begin{tabular}{|c|c|c|c|c|c|c|c|c|c|c|c|c|c|c|c|c|}
\hline & MD & $\mathbf{P H}$ & NB & PL & PW & PT & NFP & NUP & NTP & NRN & SL & SW & ST & W50S & SWP & $\mathbf{S}$ \\
\hline$\overline{\text { FD }}$ & 0.401 & -0.467 & -0.377 & 0.334 & 0.247 & 0.362 & -0.390 & -0.238 & -0.435 & -0.150 & 0.807 & 0.712 & 0.729 & -0.529 & -0.146 & -0.342 \\
\hline MD & & -0.270 & 0.077 & -0.263 & -0.294 & 0.385 & -0.059 & -0.081 & -0.077 & -0.566 & -0.206 & -0.231 & -0.018 & $-0.772 *$ & 0.207 & -0.059 \\
\hline PH & & & 0.518 & -0.278 & -0.336 & -0.237 & 0.142 & 0.168 & 0.179 & 0.275 & -0.250 & -0.227 & 0.113 & 0.365 & 0.317 & 0.681 \\
\hline NB & & & & -0.165 & 0.142 & 0.389 & 0.635 & -0.443 & 0.511 & 0.143 & -0.362 & -0.586 & -0.349 & -0.090 & -0.447 & 0.617 \\
\hline PL & & & & & 0.004 & 0.338 & -0.195 & 0.005 & -0.186 & 0.374 & 0.554 & 0.166 & 0.434 & -0.393 & -0.468 & -0.323 \\
\hline PW & & & & & & 0.081 & 0.451 & -0.533 & 0.309 & 0.294 & 0.419 & 0.432 & -0.105 & 0.294 & -0.727 & -0.198 \\
\hline PT & & & & & & & -0.191 & $-0.794 *$ & -0.374 & -0.477 & 0.224 & -0.175 & 0.150 & -0.680 & -0.537 & 0.387 \\
\hline NFP & & & & & & & & 0.008 & $0.972 * *$ & 0.567 & -0.389 & -0.397 & -0.613 & 0.164 & -0.465 & -0.122 \\
\hline NUP & & & & & & & & & 0.246 & 0.407 & -0.261 & -0.046 & 0.004 & 0.167 & 0.645 & -0.497 \\
\hline NTP & & & & & & & & & & 0.648 & -0.439 & -0.396 & -0.592 & 0.199 & -0.298 & -0.236 \\
\hline NRN & & & & & & & & & & & 0.193 & 0.141 & 0.061 & 0.334 & -0.300 & -0.352 \\
\hline SL & & & & & & & & & & & & $0.867 *$ & $0.827 *$ & -0.113 & -0.316 & -0.225 \\
\hline SW & & & & & & & & & & & & & 0.719 & 0.206 & 0.012 & -0.322 \\
\hline ST & & & & & & & & & & & & & & -0.226 & 0.143 & 0.007 \\
\hline W50S & & & & & & & & & & & & & & & 0.157 & 0.130 \\
\hline SWP & & & & & & & & & & & & & & & & 0.053 \\
\hline
\end{tabular}

Note: $\mathrm{FD}=$ flowering date (day), $\mathrm{MD}=$ maturity date (day), $\mathrm{PH}=$ plant height $(\mathrm{cm}), \mathrm{NB}=$ number of branches plant ${ }^{-1}, \mathrm{PL}=$ pod length $(\mathrm{mm}), \mathrm{PW}=$ pod width $(\mathrm{mm}), \mathrm{PT}=$ pod thickness $(\mathrm{mm}), \mathrm{NFP}=$ number of filled pods plant ${ }^{-1}, \mathrm{NUP}=$ number of unfilled pods plant ${ }^{-1}$, $\mathrm{NTP}=$ number of total pods plant ${ }^{-1}, \mathrm{NRN}=$ number of reproductive nodes plant ${ }^{-1}, \mathrm{SL}=$ seed length $(\mathrm{mm}), \mathrm{SW}=$ seed width $(\mathrm{mm}),=$ seeds thickness $(\mathrm{mm}), \mathrm{W} 50 \mathrm{~S}=$ weight of 50 seeds $(\mathrm{g}), \mathrm{SWP}=$ seed weight plant ${ }^{-1}(\mathrm{~g}), \mathrm{S}=$ disease severity $(\%), *=$ significant at $5 \%$, ** $=$ significant at $1 \%$ 
The seed length of each plant had a very significant correlation to the seed width and seed thickness with a correlation value of 0.867 and the seed width of 0.827 . However, there was no correlation between seed width and thickness. The speed of seed filling and the seed size can give a relatively high seed weight (Sutoro et al. 2008). Sharma (2003) showed that the traits of seed size are one factor influencing the soybean product. The soybean seed size influences the increase of soybean production (Aulia et al. 2014).

In conclusion, nitrogen affected number of filled, unfilled pods and total pods, number of reproductive nodes, and seed weight per plant. These traits showed interaction between genotype and nitrogen. Nitrogen did not affect pod length, pod width, plant height, and flowering date. In these traits, there was no significant different. These traits were more affected by the genotype. The interaction led the genotypes had different responses to the agronomical trait after they were treated with nitrogen depending on the need of each genotype of the soybean plant. It means that the use of nitrogen fertilizer in a specific dose for a specific genotype can be a solution in increasing the soybean production by increasing the size and weight of soybean seed and pod.

\section{ACKNOWLEDGEMENTS}

Thanks to the DRPM DIKTI for the Higher Education Basic Research grant funding No. 1.3.44/UN32.14/LT/ 2018.

\section{REFERENCES}

Ahsan MMR, Akter MS, Alam, Haque MMA. 2012. Nodulation, yield and quality of soybean as influenced by integrated nutrient management. Journal Agrofor Environ 6 (1): 33-37.

Alam F, Bhuiyan MAH, Alam SS, Waghmode TR, Kim PJ, Lee YB 2015. Effect of Rhizobium sp. BARIRGm901 inoculation on nodulation, nitrogen fixation and yield of soybean (Glycine max) genotypes in gray terrace soil. Bioscience, Biotechnology, and Biochemistry 79 (10): 1660-1668. DOI: 10.1080/09168451.2015.1044931

Andayani WR, Sumardiyono YB, Hartono S, Yudono P. 2011. Incidence of soybean mosaic disease in east java province, Agrivita 33 (1): $026-$ 053.

Asanuma K, Bayorbor TB, Kogure JO, Anim, Suzuki. 1992. Studies on the response of nodulated soybean to $\mathrm{N}$ fertilizer. Japanese J Crop Sci 6 (1): 432-438

Aulia R, Rosmayati, Bayu ES. 2014. Growth response and production of black soybean varieties (Glycine max. L ) based on seed size. Jurnal Online Agroekoteknologi 2 (4): 1324-1331. [Indonesian]

Brown JK. 2014. Cowpea Mild Mottle Virus Carlavirus: Betaflexiviridae; order Tymovirale. School of Plant Sciences, University of Arizona.

Chafi AA, Amiri E, Nodehi DA. 2012. Effects of irrigation and nitrogen fertilizer on soybean (Glycine max) agronomic traits. Intl J Agric Crop Sci 4 (16): 1188-1192.

Chu Q, Watanabe T, Shinano T, Nakamura T, Oka N, Osaki M, Sha Z. 2016. The dynamic state of the ionomer in roots, nodules, and shoots of soybean under different nitrogen status and at different growth stages. J Plant Nutr Soil Sci 179 (4): 488-498.

Ebony YJ, Boykin LSS, Lodhi MA. 2010. Callus induction and organogenesis in soybean (Glycine max (L.) Merr.) cv. pyramid from mature cotyledons and embryos, Open Plant Sci J 4: 18-21.
Efendi. 2010. Increasing growth and production of soybeans through a combination of organic fertilizer of lamtorogung and manure. Jurnal Floratek 5 (1): 65-73. [Indonesian]

Golparvar P, Mirshekari B, Borhani P. 2012. Nitrogen spraying of soybeans at earlier flowering stage will be an ecological friendly fertilization management and improve crop yield. World Appl Sci j 19 (10): 1388-1392.

Hakim L. (2012). Yield components and determinant morphological characters of soybean yield. Penelitian Pertanian Tanaman Pangan 31 (3): 173-179. [Indonesian]

Hasnah. 2003. Effect of shade on the growth of soybean and peanut. J Agromet 8 (1): 21-40. [Indonesian].

Islam MM, Ishibashi Y, Nakagawa ACS, Tomita Y, Iwaya-Inoue M, Arima S, Zheng SH.2016. Nitrogen redistribution and its relationship with the expression of GmATG8c during seed filling in soybean. J Plant Physiol 192: 71-74.

Jiu M, Zhou X-P, Tong L, Xu J, Yang X, Wan F-H, et al. 2007. Vectorvirus mutualism accelerates population increase of an invasive whitefly. PLoS ONE 2 (1): e182. DOI: 10.1371/journal.pone.0000182

Kuswantoro H, Hapsari RT, Sulistyo A, Supeno A. 2017a. Potential yield of tidal swamp-adaptive soybean promising lines. Legume Res 40 (3): 514-519.

Kuswantoro H, Sudaryono, Suharsono, Widodo Y, Tahir Y, Soetajan W, Tarigan M, Candradidjaya A. 2017b. Effect of soil tillage and adaptability of Argomulyo and Burangrang varieties in Madagascar dry season with cold temperature. Agrivita 39 (1): 11-20.

Kuswantoro H, Zubaidah S, Sulisetijono. 2014. Decreasing grain size caused declining grain yield of CpMMV resistant soybean lines grown in ultisol. J Biol Sci 14 (8): 508-514.

Kuswantoro H. 2015. Increasing grain size improves grain yield of acidadaptive soybean lines in optimal soil condition. J Plant Sci 10 (3): 79-89.

Laguna IG, Arneudo JD, Pardina PR, Fiorona M. 2006. Cowpea Mild Mottle Virus infecting soybean crops in northwestern Argentina. Fitopatologia Brasileira 3 (1): 317-317.

Liu Y, Jiang X, Guan D, Zhou W, Ma M, Zhao B, Cao F, Li L, Li J. 2017. Transcriptional analysis of genes involved in competitive nodulation in Brady Rhizobium diazoefficiens at the presence of soybean root exudates. Sci Rep 7: 10946. DOI: 10.1038/s41598-017-11372-0

Mahesh N, Sreenivas G, Rani PL, Gupta A, Sreekanth PD, Madavi A. 2017. Influence of Sowing Dates and Plant Densities on Dry Matter Production and Nitrogen Uptake of soybean under south Telangana agro-climatic zone of Telangana State. Intl J Curr Microbiol Appl Sci 6 (8): 2061-2066. DOI: 10.20546/ijcmas.2017.608.245

Marlina E, Anom E, Yoseva S. 2015. Effect of organic NPK fertilizer on soybean (Glycine $\max (\mathrm{L}$.) Merril) growth and production. Jurnal Online Mahasiswa Faperta 2 (1): 1-13. [Indonesian]

McCoy JM, Kaur G, Golden BR, Orlowski JM, Cook DR, Bond JA, Cox MS. 2018. Nitrogen Fertilization of Soybean Affects Root Growth and Nodulation on Two Soil Types in Mississippi. Commun Soil Sci Plant Anal 49 (2): 181-187. DOI: 10.1080/00103624.2017.1421649

Mehmet OZ. 2008. Nitrogen rate and plant population effects on yield and yield components in soybean. African J Biotechnol 7 (24): 16845315.

Meliala C. 2009. Introduction to Plant Disease. UGM Press, Yogyakarta. [Indonesian]

Ohyama T, Tewari K, Ishikawa S, Tanaka K, Kamiyama S, Ono Y, Hatano S, Norikuni O, Sueyoshi K, Hasegawa H, Sato T, Tanabata S, Nagumo Y, Fujita Y, Takahashi Y. 2017. Role of nitrogen on growth and seed yield of soybean and a new fertilization technique to promote nitrogen fixation and seed yield. In: Minobu Kasai (ed.). Soybean - The Basis of Yield, Biomass and Productivity. IntechOpen Limited. London, UK. DOI: 10.5772/66743.

Osborne S L, Riedell WE. 2006. Starter nitrogen fertilizer impact on soybean yield and quality in the northern great plains. Agron J 98 (6): 1569-1574. DOI: 10.2134/agronj2006.0089

Schiltz S, Munier-Jolain N, Jeudy C, Burstin J, Salon C. 2005. Dynamics of exogenous nitrogen partitioning and nitrogen remobilization from vegetative organs in pea revealed by $15 \mathrm{~N}$ in vivo labeling throughout seed filling. Plant Physiol 137 (4): 1463-1473. DOI: 10.1104/pp.104.056713

Seghatoleslami MJ, Bradaran R, Elham A, Mousavi SG. 2012. Effect of irrigation and nitrogen level on yield, yield components and some morphological traits of sunflower. Pakistan J Bot 44 (5): 1551-1555. 
Sharma DJ. 2003. Path coefficient analysis of yield attributes in soybean. J Genet Plant Sci 8: 115-117.

Sinclair JB. 1993. Compendium of Soybean Disease. Sec. ed. The American Phytopathology Society. St. Paul. MN.

Song Y, Nakajima T, Xu D, Homma K, Kokubun M. 2017. Genotypic variation in salinity tolerance and its association with nodulation and nitrogen uptake in soybean. Plant Prod Sci 20 (4): 490-498. DOI: 10.1080/1343943X.2017.1360140

Soverda N, Hermawati T. 2009. Response of soybean (Glycine max (L.) Merill) to various concentrations of biological fertilizers. Jurnal Agronomi 13 (1): 6-12. [Indonesian]

Suryadi YS, Akhdiya MA, Manzila A, Wawan. 2012. Evaluation of soybean germplasm for its resistance to several foliar pathogens in Indonesia. J Agric Technol 8 (2): 751-763.

Sutoro, Dewi N, Setyowati M. 2008. Relationship between morphophysiological traits and seed yields of soybean. Penelitian Pertanian Tanaman Pangan 27 (3): 185-190. [Indonesian]

Sutrisno, Kuswantoro H. 2016. Cowpea Mild Mottle Virus (CpMMV) Infection and Its effect on performance of South Korean soybean varieties. Biodiversitas 17 (1): 2085-4722.

Taggar GK, Gill RS. 2012. Preference of whitefly, Bemisia tabaci, towards black gram genotypes: Role of morphological leaf characteristics. Phytoparasitica 40 (5): 461-474.

Tang F, Yang S, Liu J, Zhu H. 2016. Rj4, a gene controlling nodulation specificity in soybeans, encodes a thaumatin-like protein but not the one previously reported. Plant Physiol 170 (1): 26-32. DOI: 10.1104/pp.15.01661

Tewari K, Sato T, Abiko M, Ohtake N, Sueyoshi K, Takahashi Y, Nagumo Y, Tutida T, Ohyama T. 2007. Analysis of the nitrogen nutrition of soybean plants with deep placement of coated urea and lime nitrogen. Soil Sci Plant Nutr. 53 (6): 772-781. DOI: 10.1111/j.1747-0765.2007.00194.x

Wartono, Laba IW, Wawan. 2011. Effectiveness of BPMC application against Bemisia tabaci (Gennadius) population and CMMV disease incidence on soybean. Indonesian center for agricultural biotechnology and genetic. J Entomol Indonesia 8 (2): 63-72.

Werner F, Balbinot Junior AA, Ferreira AS, Silva MAA, Debiasi H, Franchini JC. 2016. Soybean growth affected by seeding rate and mineral nitrogen. Revista Brasileira de Engenharia Agrícola e $\begin{array}{lllll}\text { Ambiental } 20 & \text { (8): } & 734-738 . & \text { DOI: } & 10.1590 / 1807-\end{array}$ 1929/agriambi.v20n8p734-738

Wood CW, Torbert HA, Weaver DB. 1993. Nitrogen fertilizer effects on soybean growth, yield, and seed composition. J Prod Agric 6 (3): 354360 .

Yagoub SO, Ahmed WMA, Mariod AA. 2012. Effect of urea, NPK and compost on growth and yield of soybean (Glycine max L.), in semiarid region of Sudan. International Scholarly Research Network (ISRN) Agronomy 6 (12): 1-6.

Yan Z, Hossain MS, Arikit S, Valdés-López O, Zhai J, Wang J, Libault M, Ji T, Qiu L, Meyers BC, Stacey G. 2015. Identification of microRNAs and their mRNA targets during soybean nodule development: functional analysis of the role of miR393j-3p in soybean nodulation. New Phytol 207 (3): 748-759.

Zhao X, Zheng SH, Arima S. 2014. Influence of nitrogen enrichment during reproductive growth stage on leaf nitrogen accumulation and seed yield in soybean. Plant Prod Sci 17 (3): 209-217. DOI: 10.1626/pps.17.209

Zubaidah S, Kuswantoro H. 2016. Foliar symptoms recovery: developing scoring technique for assessment of soybean resistance to CpMMV (Cowpea Mild Mottle Virus). J Biol Res 21 (2): 85-89. 